\title{
IS PHILOSOPHY ALL ABOUT THE MEANING OF LIFE?
}

\begin{abstract}
I defend the view that the factor which unifies the academic discipline of philosophy is the question of the meaning of life; I take this to be a popular view outside of philosophy, though a very unpopular one within it. Firstly, in Section 2, I argue against a wide range of exceptionalist theses according to which philosophy is unique among academic disciplines in not being united by a distinctive subject-matter. These are the views that philosophy can be applied to any topic; that philosophy is united by methodology; that philosophy is a genealogical linkage; that philosophy cannot be defined because it is too controversial - or because it is essentially self-reflective - and hence any attempted definition will embody a partisan philosophical position; and that philosophy consists in speculation on topics which cannot yet be treated scientifically. I begin Section 3 by arguing that metaphilosophical positions closely allied to a philosophical agenda cannot reveal what unifies the discipline, and that the unity of philosophy cannot be accounted for solely in terms of its concerns with fundamentality or generality. I then present my positive account, showing that the issue of the meaning of life is uniquely able to reveal unity between the practical and theoretical concerns of philosophy, while meeting a range of desiderata - based on both conceptual and historical considerations - for a typical specification of subject-matter. I also argue that the recently arisen paradigm within analytic philosophy for investigating the meaning of life has served to conflate the traditional question with an issue about social meaningfulness, and that the former question is of considerably more philosophical interest. Finally, in Section 4, I provide an account of why the meaning of life has been marginalised in philosophy, and as a consequence, why philosophy's subject-matter has become shrouded in obscurity. The main
\end{abstract}


factors have been philosophy's need to demonstrate professional expertise, while aligning itself with science and distancing itself from religion, and also the pathological connotations of concern with the meaning of life. These are not good reasons, however, and I conclude that philosophy should embrace its popular image.

\section{Keywords}

Metaphilosophy; Philosophy of Philosophy; Subject-matter of Philosophy; Meaning of Life

\section{Word Count}

7983

\section{The Popular Imagine of Philosophy}

To say that football is 'all about scoring goals' may be considered a philistine judgement, but it conveys a certain basic truth. Trying to score goals is what the game revolves around. Likewise, to say that palaeontology is 'all about fossils' similarly succeeds in getting important information across, which would be considered salient by someone who knew the name but not what it stands for. Of course, you might object that it is not all about fossils, because fossils are just the principal source palaeontologists have for studying life before the Holocene Epoch. But that would be to enter into more controversial waters which lie beyond the typical intention of such a statement, which would not normally be used as an attempt at definition, but rather to focus the mind on a typical unifying factor. The unification may be historical rather than conceptual: maybe there could be football without goals or palaeontology without fossils, but football and palaeontology have not typically been like 
that. It is in this ordinary and loose sense of 'all about', then, that I shall defend the professionally unpopular view that philosophy is all about the meaning of life.

Professionally, but not otherwise unpopular, for philosophy and the meaning of life are indelibly linked in the public imagination. I am not alone in thinking this. E.D. Klemke, for instance, imagined the reaction of 'the ordinary man' to hearing some typical titles of analytic philosophy papers ('On Referring', 'The Problem of Counterfactual Conditions’, etc.), being: 'What's this all got to do with philosophy?' (Klemke 2008: 185) For that man was expecting to hear about the meaning of life. And David Cooper reports the 'rumour' that 'a main motive for making formal logic a compulsory first-year course at Oxford was to disabuse students of their image of philosophy as preoccupied with the meaning of life.' (Cooper 2003: 127) I myself was once swiftly disabused of this image; a process which produces that distinctive combination of a lack of clarity about the subject-matter of philosophy with an indifference to such second-order concerns, which is typical of many professional philosophers.

Of course, whether or not this is the popular image of philosophy an empirical question. But I do not need concrete support, since I am not about to argue that whatever the public thinks must be right; ‘50,000,000 Elvis Fans Can’t Be Wrong’, declared the title of a Presley compilation ... but they might have been. My point is only this: if you share my impression of philosophy's public image, then you have good reason to wonder what lies behind it. Philosophy’s professional self-image, by contrast, provides no encouragement to my thesis, since it takes the meaning of life to be just one minor and specialised philosophical topic, dwarfed by scores of more central metaphysical, epistemological, logical and moral ones. This remains true despite the resurgence of philosophical interest which the meaning of life 
has enjoyed in recent years; the direction this has taken strikes me as regrettable, for reasons I shall explain, but that will only be a side-issue.

I will proceed as follows. In the next section I will argue that philosophy must have a distinctive subject-matter, against a range of philosophers who have thought it is unique among academic disciplines in not having one. Then in Section 3 I will argue that the meaning of life is the best candidate for playing this role. Finally, in Section 4 I will explain why I think this answer is professionally unpopular, and why it should not be.

\section{Exceptionalism}

Perhaps philosophy is unique among academic disciplines because you can philosophise about anything. This view gains credence from the apparently inexhaustible range of topics philosophers turn their hand to these days: there is philosophy of football (McGinn 2008), palaeontology (Turner 2011), and wine (Smith (ed.) 2007), for instance. But this cannot be right, because you could not have a philosophy of sycamore trees; this topic is too specific. A philosopher might tell you that sycamores, like all physical objects, are simply arrays of sense-data. But by moving the discussion onto their turf in this manner, sycamores become irrelevant. For a biologist, by contrast, distinctions between types of trees can be relevant to their expertise.

Philosophers are not the only academics who discuss a wide range of topics. Psychologists can tell us interesting things about football, as can chemists about wine. However what makes this interesting is the application of expertise to a topic; when the chemist stops talking chemistry, then her opinions about wine are, ceteris paribus, as good as anyone's. Not only is 
it hard to see why philosophy should be any different in this regard, but it also seems clear that the familiar phenomenon of professional expertise being applied to a slightly outré topic is exactly what happens when philosophers discuss football, palaeontology or wine: they talk about the nature of aesthetic judgements, epistemological considerations, and other typically philosophical matters, as applied to the topic in question. This expertise typically operates at a high level of generality, which explains why philosophers can find so many things to talk about. But the generality of philosophical expertise provides no reason to doubt it exists; if it did not philosophers would be charlatans.

The fact that philosophers have an area of expertise does not mean it is necessarily in a subject-matter, for perhaps it is purely methodological. Perhaps there is a specific methodology the application of which qualifies thinking as philosophical. The decisive objection to this, however, is to point out that many different methodologies have been employed in philosophy, such as radical doubt, phenomenological description, conceptual analysis, and deconstruction. To try to find some unity in the fact that these are all a priori methods will not help, because mathematics is predominantly a priori, nobody would mistake ancient a priori speculations about meteorology or anatomy for works of philosophy, and philosophy has recently been supplemented with experimental methods (Knobe and Nichols (eds.) 2008). Williamson is surely right when he says: 'Forget the idea of a single method, employed in all and only philosophical thinking.' (Williamson 2007: 3)

Still, maybe there are a variety of philosophical methodologies, and philosophy occurs when one of these is used. This seems to be Williamson's view, since he calls his book The Philosophy of Philosophy because it applies the philosophical methodology he favours to that very methodology (ibid.: 5-6). However once we forget the idea of a 'single method', we are 
left with no explanation of why that methodology counts as philosophical. It would be natural to appeal to subject-matter, saying that although philosophical methodologies have nothing to unite them qua methodologies, they were all developed to answer certain types of questions. But Williamson thinks methodology determines subject-matter in philosophy, rather than the other way around, for he says that '[p]hilosophical questions are those philosophers are disposed to ask, which in turn tend, unsurprisingly, to be those more amenable to philosophical than to other ways of thinking' (ibid.: 4). Consequently he tells us nothing about what justifies calling different methodologies and questions 'philosophical': he disavows methodological unity, and yet the unity of the philosophical cannot be rooted in subject-matter either, since philosophical questions are simply those amenable to its methodologies.

This kind of aversion to subject-matter seems unique to philosophy, and perhaps the reason is that philosophy is 'the sort of thing that has a history rather than a nature' (Brandom 2001: 75). The best-known version of this claim comes from Rorty, who says,

All that "philosophy" as a name for a sector of culture means is "talk about Plato, Augustine, Descartes, Kant, Hegel, Frege, Russell . . . and that lot.” Philosophy is best seen as a kind of writing. It is delimited, as is any literary genre, not by form or matter, but by tradition. ... (Rorty 1982, p. 92)

Rorty later baulked at the degree of unity this imparts to philosophy, and so denied that philosophy is even a 'literary genre’ on the grounds that “"genre” suggests format' (Rorty 1991: 67). His considered view was that philosophy is simply 'a genealogical linkage 
connecting certain past figures with certain present figures ... an ancestral relation of overlapping fibers'. ${ }^{1}$

There are two serious flaws to this. The first is that a work of sociology or history might mention all the same philosophers' names. Passing references to their ideas might qualify the work as 'philosophical' (in this way a biography or novel can be philosophical), but in a bona fide work of philosophy the ideas are centre-stage and actively engaged with. Once a philosopher has established their credentials they might blur the boundaries a little, as did Derrida - the inspiration for Rorty's thesis - who sometimes seemed more interested in philosophers than their ideas (Derrida 1987). But Derrida was not always like this (e.g. Derrida 1978); otherwise it is doubtful he would have made it into the canon. And in any case, philosophical name-checking is clearly inessential to philosophy, for you can write philosophy without mentioning other philosophers, as the pre-Socratics typically did.

The second flaw is brought out by the context in which Rorty amended his position, namely in a correspondence over his reluctance to acknowledge the existence of non-Western philosophy. ${ }^{2}$ For philosophy, pace Rorty, has developed independently in a number of different cultures, just as mathematics and astronomy have. When these cultures first met, philosophers recognised their interests being pursued, and so started incorporating new influences into their work (Clarke 1997). Now evidently this meeting of minds did not occur

\footnotetext{
${ }^{1}$ Rorty held, to my knowledge, the second most extreme position on philosophy’s supposed lack of unity. The most extreme was held by Quine, who thought that 'philosophy' is a completely arbitrary ‘administrative and bibliothecary term' (Quine 1975: 228). All of the arguments in this paper addressed to the unity of philosophy's subject-matter count against Quine’s view; such as the present one about the meeting of Western and nonWestern philosophy, for instance.

${ }^{2}$ For analysis of why Rorty adopted this non-eclectic, and hence thoroughly un-Rortyan stance, see [deleted]
} 
because names were recognised; that is exactly what was not recognised. Rather, ideas and topics were recognised. Thus when Heidegger drew extensively on Eastern philosophy, he did so because the ideas fitted his agenda; he kept his sources hidden (May 1996).

That philosophy is not a culturally specific phenomenon - a fact which has rarely been seriously contested (Rorty and Hegel are the notable exceptions here ${ }^{3}$ ) - is the most decisive factor favouring the view that philosophy is united by subject-matter. For it is hard to see how else philosophy might ever have been recognised in other cultures. This consideration counts heavily against any methodological alternative, for although we sometimes find philosophers like Xuan-zang or Candrakīrti employing argumentative strategies uncannily reminiscent of Western philosophers, this is the exception rather than the rule. It is easy, however, to discern discussions of idealism and realism, the nature of time or mind, or the principles of moral conduct. So let us now proceed on the assumption that philosophy is like other academic disciplines in being united by its subject-matter.

Having made this small concession to normality, two more popular exceptionalist theses now raise their heads. Neither explicitly denies that philosophy has its own subject-matter. But the first denies we can specify it in any non-partisan manner, while the second denies it has the kind of unity found in other disciplines. The first comes from Russell:

We may note one peculiar feature of philosophy. If someone asks the question what is mathematics, we can give him a dictionary definition, let us say the science of number, for the sake of argument. As far as it goes this is an uncontroversial

\footnotetext{
${ }^{3}$ For Hegel, see Clarke op. cit.: 113. The reason for both Hegel and Rorty’s views is to be found, I think, in their vested interests in metaphilosophies according to which philosophy is an essentially Western phenomenon.
} 
statement (...) Definitions may be given in this way of any field where a body of definite knowledge exists. But philosophy cannot be so defined. Any definition is controversial and already embodies a philosophic attitude. The only way to find out what philosophy is, is to do philosophy. (Russell 1959: 7)

There are three influential ideas in this passage. The first is that philosophy cannot be defined because it contains no 'body of definite knowledge'. The second is that any attempt at defining it 'already embodies a philosophic attitude', and hence can never attain the theoretical neutrality required for an uncontroversial definition. And the third is that we can only find out what philosophy is by doing it.

The first will not get us far, because there are plenty of academic disciplines mired in controversy and containing no definite body of knowledge; astrobiology is a good example. But astrobiology has a subject-matter which can be specified without undue controversy: it is all about the origins and distribution of life in the universe, and in particular, whether there is extra-terrestrial life. This combination is unremarkable because subject-matter concerns what you are seeking, not necessarily what you have already found. As such, you do not need a definite body of knowledge, only some unified domain you intend to investigate.

Russell's second idea is that to inquire into the subject-matter of philosophy is already to have begun philosophising. In a slogan: metaphilosophy is a kind of philosophy. This is now so much taken for granted that 'philosophy of philosophy' is often used as if it were simply a synonym for 'metaphilosophy' (e.g. Stoljar 2010). Its upshot in the present context is that since claims about the subject-matter of philosophy are philosophical theories, and philosophical theories are controversial, an uncontroversial definition of philosophy cannot 
be given. Philosophers can say what they think philosophy is about, but this will just be an expression of their own 'philosophic attitude'.

The view that metaphilosophy is a kind of philosophy, or at least that it must be, has been insufficiently scrutinised. A typical (and typically perfunctory) attempt at a justification is offered by Allen Wood, who tells us that:

... philosophy is a self-reflective activity, and therefore 'What is philosophy?' is a philosophical question in a way that 'What is poetry?' need not be the subject of poems (though of course it can be) and 'What is physics?' is not a question for physicists (even if a knowledge of physics is needed in order to answer it). (Wood 2001: 97-8)

But it is not clear that philosophy is always terribly self-reflective; perhaps it should be, but as it stands there does not seem to be much self-reflection evidenced in the average discussion of the metaphysics of universals or the nature of reference, for instance. The reflection is squarely aimed at the topics. But even if we were to grant that philosophy is essentially self-reflective, it would not follow that reflection on its subject-matter requires this kind of reflection. It might just require the same kind of reflection needed to determine the subject-matter of any discipline, i.e. reflection - informed by knowledge of its current practice and history - on what topics it deals with and what they have in common.

Metaphilosophy is, at a minimum, reflection on philosophy. This can take a number of forms: reflection on philosophical methodology, reflection on the epistemic status of philosophical theories, or reflection on philosophy's subject-matter, to mention three prominent examples. 
The first will count as philosophy if specifically philosophical methods are employed; methods which count as philosophical because of their association with philosophical topics. A sociological discussion of philosophical methodology would not so count. But even when such methods are not employed, if the discussion is by a philosopher, and conducted to advance discussion on philosophical topics, this may still be enough to classify it as philosophy. The second example inherits its philosophical status more directly, because it concerns epistemic status, which is prime philosophical territory. In this case, the metaphilosophical reflection itself requires the discussion of philosophical topics.

But the status of the third kind of reflection is more tenuous. It is the topic of this essay; but have I done any actual philosophy yet? I have not said anything about philosophical topics, though some have been mentioned; as they might be in a purely historical study. Neither have I employed specifically philosophical methodology: I have not asked the reader to bracket existential assumptions about phenomena, for instance. I have argued in a manner which is typical in philosophy, by progressing from claim to counterclaim to claim, etc. But argumentatively structured prose is standard throughout academia; apart from some science and mathematics, the clearest exception to this rule comes from more radical kinds of philosophy, together with those humanities and social sciences it has influenced. And even outside of academia, the approach I have taken is far from uncommon among lawyers, politicians, and journalists. Philosophy is widespread, but not as thoroughly ubiquitous as reasoned argument; and it can exist in recognisable form with a surprising dearth of the latter.

It might be objected that I have engaged in conceptual analysis. But although the conceptual analysis of the ordinary language philosophers was a paradigmatically philosophical methodology, that is because it was hedged by various philosophical assumptions and 
employed for the purposes of dissolving philosophical problems. Outside of this context, however, it is not a plausible criterion of philosophy. A discussion among palaeontologists about whether their discipline can sometimes legitimately include the Holocene Epoch might similarly be construed as an exercise in conceptual analysis, without being in the least philosophical. If it brought in Kuhn's theory of scientific revolutions, for instance, this might tip the balance, but simply having a reasoned discussion about definitional matters cannot be enough. And if it were enough, definitions of philosophy would not enjoy exceptional status; definitions of palaeontology would be equally problematic because 'philosophical'

Russell's third idea is that you can only find out what philosophy is by doing it. It does not sit easily with the others, which suggest you can never 'find out' what philosophy is. But it has been similarly influential, as is attested to at the outset of innumerable general introductions to philosophy: rather than seek a formula, neophytes are sagely advised, just get stuck in! This seems to have been Moore’s attitude when he disappointed natural expectations regarding the question 'what is philosophy?' by saying it was the topic of the books on his bookshelves (Flew 1979, p. vii). This idea combines an encouragement to dismiss the question, with the positive proposal that 'doing' philosophy will provide you with an enumerative grasp of its subject-matter, which is all you should want; and in any case all you can get. But we have seen no good reason to dismiss the question. And an enumerative grasp of the subject-matter of philosophy does not provide an answer, though of course you need it to begin looking for one. We can all list typical philosophical topics, but that ability does not in itself reveal the common factor which justifies calling them all 'philosophical', if indeed there is one. 
Let us turn to the second exceptionalist thesis, according to which the subject-matter of philosophy lacks the unity found in other disciplines, that is, some commonality inherent to the various issues treated. For according to this view, philosophical topics are simply those that have been left behind by the advance of science, and have nothing in common except our present inability to treat them scientifically. It originates with Comte's positivism, according to which 'each branch of our knowledge, passes successively through three different theoretical stages: the theological or fictitious, the metaphysical or abstract, and the scientific or positive' (Comte 1842 / 1974: 20); philosophy is the second stage. So philosophy is an $a$ priori, speculative stage of inquiry, which offers an improvement on mythological or religious explanations, but which is destined for eventual replacement by a programme of empirical research. As J.O. Urmson memorably put it, it is the 'fissiparious mother of all the sciences’ (Urmson 1960: 11).

This view gains some plausibility from history, since both psychology and cognitive science emerged from philosophy then left it behind. However other considerations suggest these were simply cases of philosophical and scientific interests overlapping. The first is that there seems a clear distinction between highly speculative new sciences and philosophy; principally that they deal with different topics. Quantum biology is brand new and highly speculative, but it is not philosophy. However this judgment may be prejudiced by our familiarity with traditional philosophical topics. Realising this, some might bite the bullet and declare quantum biology to be currently at a purely philosophical stage; perhaps Comte’s view has been influential enough for this not to sound entirely outlandish.

A more convincing consideration is that empirical methods have now been introduced into philosophy, and yet in all the controversies experimental philosophy has generated, the idea 
that it will usurp other kinds, or even cause philosophy to cease to exist, has not been prominent. Its best-known advocates explicitly disavow any such agenda, saying their proposal is 'just to add another tool to the philosopher’s toolbox' (Knobe and Nichols 2008: 10). And surely the reason philosophy has been able to be supplemented in this manner, and that experimental philosophy was not immediately dismissed as a contradiction in terms - as it must be on Comte's view - is that philosophy has a distinctive subject-matter. Philosophers appeal to intuitions, intuitions can be empirically determined, and so when the intuitions investigated in this way concern philosophical topics, the result is experimental philosophy.

The most decisive consideration, however, is that the subject-matter of philosophy simply does not look like the ragtag collection of random topics this thesis would lead you to expect. On the contrary, questions about appearance and reality, representation and knowledge, reason and unreason, moral and immoral action, and so on, do seem to lead into one another, such that it is not surprising to find philosophers moving between these themes, and traditionally integrating them into systems. And this impression of unity is reinforced by the fact that philosophers from the Greeks onwards grouped their treatments of these topics together within unified texts; many great philosophers were polymaths, but what we now think of as the core topics of philosophy were not generally extracted and pieced together from general works giving equal prominence to, for instance, scientific and mathematical matters. Rather, within any of the acknowledged classics you might care to mention, a selection of these topics were presented together as a unified whole. 


\section{Metaphilosophy and the Meaning of Life}

Having now considered a range of exceptionalist theses and found them all wanting, let us settle on the default view that philosophy is like all other academic disciplines in having a distinctive subject-matter. What strikes me most forcibly from our previous discussion is the lengths philosophers have gone to in order to deny this, when it is what any outsider would expect from the outset, and when the enumerative grasp of the various topics which insiders acquire points in exactly the same direction. It is as if it were so hard to discern any unity to this subject-matter that philosophers have been prepared to grasp at straws in order to avoid the conclusion that there is one. But it cannot be that hard if I am right that the answer is embodied in philosophy's public image. This suggests that some other factor must be motivating this evasion, which is a lead I shall follow up in the final section.

Before moving onto my positive proposal, we should first consider alternative proposals for what this distinctive subject-matter consists in. This will not delay us long, however, because they have almost always been obviously partisan, and barely distinguishable from proposals for what the subject-matter of philosophy ought to be, if they display any reticence about their promulgating intentions at all. This is the root of Russell's view that attempts to define philosophy always embody a 'philosophic attitude'. But Russell confused the fact that most of the best-known statements about the nature of philosophy have been part of a manifesto on behalf of a particular philosopher or school, with the existence of some principled reason why a neutral unifying factor cannot be stated.

Thus Aquinas thought philosophy was the handmaiden of theology, Descartes thought it was the underwriter of science, Locke thought it under-laboured for science, Hegel thought it was 
an all-encompassing system of reason, Ayer thought it was analysis of how language relates to experience, Heidegger thought it was an openness to Being ... all these views indicate the kind of topics philosophy should be investigating. But the indications conflict by making certain topics central and excluding others, despite the fact that almost everything the above figures discussed is recognisable as philosophy. This exclusion is inevitable when metaphilosophical commitments are shadows of new philosophical developments; philosophers start analysing the underlying form of language, and then feel impelled to say that philosophy is all about analysing the underlying form of language. Since a metaphilosophy distinctive enough to characterise a new philosophical development can never be entirely uncontroversial, something is bound to be excluded. Even when efforts towards inclusivity are made, as when Ayer said, 'the majority of those who are commonly supposed to have been great philosophers were primarily not metaphysicians but analysts’ (Ayer 1946 / 2002: 52), there still have to be losers (in this case metaphysicians), otherwise a distinctive niche will not have been carved out.

We should always be suspicious when a metaphilosophical claim of this kind is intimately connected with its advocate's philosophy. This is not simply because we must accept the philosophy to accept the metaphilosophy; for maybe we should. It is rather because if the philosophy is original, this raises the question of why philosophical topics were grouped together before. Thus when McGinn says that philosophical problems are those which occur when we try to 'force our cognitive faculties to deliver knowledge of phenomena whose nature those faculties are not cut out to comprehend' (McGinn 1993: 150), you have wonder why those problems were thought philosophical before he devised his 'cognitive closure' 
thesis. ${ }^{4}$ There must have been some surface commonality, and it is this, rather than a philosophical analysis of that commonality, which promises the kind of insight into philosophy’s subject-matter which is so readily available for other disciplines. Brandom’s view of philosophy as 'awareness of ourselves as specifically discursive (that is, conceptmongering) creatures' (Brandom 2001: 92) would suffer the same flaw, if it were not for his candid admission that he is trying to 'reconstruct' the philosophical tradition, which he thinks is the only way to move beyond Rorty’s genealogical position. But once exceptionalist theses are abandoned, there is no reason to think that either philosophical theories or imaginative reconstruction should be required.

If philosophy is unexceptional, then we are looking for something considerably blander, and proposals of this kind are hard to come by. The most influential is that philosophy studies that which is most fundamental, or in a similar vein, that it asks the most general questions about reality. This is the encyclopaedist's favourite, but there are serious problems with it. For 'fundamental' requires philosophical explication to do the work required of it, since it does not direct our attention to an already familiar phenomenon in the way 'living organisms', 'fossils', or 'numbers' do. 'Fundamental to whom or to what?' you might reasonably ask. To reality? But then what distinguishes philosophy from fundamental physics? If we bring in philosophical theories concerning idealism and realism, we can make the case that philosophy concerns a wider issue according to which physics may or may not be fundamental. But fundamental physics is still fundamental physics, so we will have to distinguish fundamentality in the philosophical sense from fundamentality in the physical

\footnotetext{
${ }^{4}$ McGinn might say: because of our inability to solve those problems. But most of the great philosophers did not believe we were thus unable, and people have found themselves unable to solve many other kinds of problems.
} 
sense. And this then reduces us to saying that philosophy studies what is philosophically fundamental, which obviously fails to provide the insight sought. ${ }^{5}$

We might say that philosophical fundamentality is more fundamental than other kinds because it is more general; in which case generality is now doing all the work. But though this might succeed in characterising certain metaphysical concerns, it will not capture what is distinctive about philosophy as a whole. For questions about knowledge and morality are just as central to philosophy, but they are not the most general questions we can ask. Knowledge and morality may well be specific to human beings, and even if they are not, there are many more general phenomena we can inquire about; on the face of it, geography asks more general questions than epistemology, ethics, aesthetics, philosophy of language, or any other area of philosophy apart from ontology.

I am not saying this kind of answer is without merit. On the contrary, I think appeals to fundamentality and generality are on the right lines, and make more headway in explaining the distinctiveness of philosophy than any of the other proposals we have considered. They direct our attention to something relevant, and at least provide an answer of the appropriate, unexceptional kind. However, I think we can do better along the following lines.

The meaning of life is something which has always concerned people; just like the weather and stars. This is confirmed by both historical and conceptual considerations. On the historical side we need look no further than the phenomenon of religion, the roots of which

\footnotetext{
${ }^{5}$ Note that if philosophical fundamentality gets us into issues of maximally general ontological typing, or minddependence vs. independence, then metaphilosophy cannot count as philosophy on this criterion, since it does not investigate the fundamental nature of philosophy in this sense.
} 
may be multi-faceted, but can hardly fail to include the fact that religions provide their followers with a take on the meaning of life. ${ }^{6}$ In addition, the oldest work of literature which is still substantially extant shows a clear preoccupation with this issue; and you cannot get much better evidence for the antiquity of an intellectual concern than that. It follows King Gilgamesh's quest for the meaning of life, and culminates (in one version) with his receiving the startlingly modern-sounding advise to '[m]ake merry each day, dance and play day and night! (...) Gaze on the child who holds your hand, let your wife enjoy your repeated embrace!' (George (trans.) 1999: 124) Literary preoccupation with the meaning of life has continued unabated through Shakespeare to David Foster Wallace.

On the conceptual side, it is easy to see that this is an issue people were bound to raise. We all know the kind of activities we typically fill our lives with. And we are also aware of why we do these things, or at least can draw on background awareness when required; if serious doubts arise we wonder whether we should continue. This is because, as Cooper puts it, '[h]uman beings are inveterately teleological beings' (Cooper 2003: 126): we cannot resist looking for purposes, which is a practical stance that has clearly served us well. It is a simple and obvious step from this mundane teleological thinking to wonder about the overall purpose of life. We know the purposes of our individual activities, in terms of how they serve our own interests, those of others, or society as a whole, but it is not so clear what the purpose of human life generally is, and by extension, the purpose of my life as an example of that more widespread phenomenon. For most people, past and present, this line of thought terminates with the acceptance of a religious answer.

\footnotetext{
${ }^{6}$ This answer may not always be as explicit as in the Abrahamic religions, but I cannot think of a clear example of a major faith in which it is not there in some shape or form.
} 
Now the meaning of life is a paradigmatically philosophical issue. Perhaps it is also a paradigmatically religious issue (or just a philosophical one that religions take a stance on), and perhaps some would say that other fields of inquiry, such as biology, are now better placed to address it. But nevertheless, insiders and outsiders alike can surely agree that we are now talking philosophy. And it is an issue which is very much in the public domain. Like the stars and weather it is something people naturally wonder about, and as such, provides a natural subject-matter for an academic discipline; especially one of antiquity such as philosophy, as opposed to one concerned with more rarefied issues that have come to our attention in the course of inquiry. In this, the meaning of life is almost unique among paradigmatic philosophical issues. The only other issues of this kind are moral ones. So the meaning of life and morality look like the prime candidates for providing the kind of answer we seek.

The main problem in discerning what is distinctive in philosophy's subject-matter, it seems to me, is the apparently stark divide between its metaphysical and epistemological concerns on the one hand, and its moral ones on the other; between its theoretical and practical branches. Unless some unity can be found, the designation of both as 'philosophical' is bound to seem arbitrary. And this is where the issue of the meaning of life comes into its own. For to inquire about the meaning of a particular activity within life is to seek to place it within a wider context; whether in terms of the individual's wider aspirations or, at a greater distance, those of society at large. When inquiring about the purpose of life itself, then, it is only natural to wonder whether there is some wider context in which human life can be placed. ${ }^{7}$ And not only is this natural, it has been the common procedure within all the great philosophical

\footnotetext{
${ }^{7}$ Note that I am not claiming, absurdly, that we must move to a wider context than life to answer any question; only that this is where the question of the meaning of life takes us.
} 
traditions, through the hypothesis that reality transcends the world we perceive. For if it does so, this fundamental reality might provide the wider context in which life has meaning. This line of thought combines metaphysics and epistemology; the former in making a claim about fundamental reality, and the latter in its renouncement of perceptual access to it. It is predominant in pre-Socratic Western philosophy ${ }^{8}$, as well as in early Chinese and Indian philosophy. And in all these traditions, it leads directly into moral conclusions.

Thus for Laozi, conformity to the Dao - which is hidden from perception - provides moral guidance by inculcating otherwise overlooked virtues such as inactivity; while Buddhist philosophy teaches us to detach ourselves from the illusory world of perception in order to achieve tranquillity and salvation. But in the Western tradition, it is with Plato that the unity of philosophy's distinctive combination of metaphysical, epistemological and moral concerns becomes most evident. Plato argues that to account for the generality of conceptual thought, the particular objects and events we perceive must be transcended by a reality of universals. It is the philosopher-kings' knowledge of this fundamental reality which qualifies them to tell others how to live, since only they know the meaning of life it reveals. In light of this knowledge, they renounce material pleasures and focus their minds on true reality, realising that only in this way can their immortal souls be purged of the imperfection which caused them to lose sight of the forms 'beyond the heavens' (Phaedrus 247c; Plato 1961: 494) and thereby take on illusory mortal guise. So the meaning of life is to put our flawed lives as human beings behind us.

In Plato, then, it is easy to see how a natural concern with the meaning of life might lead into issues of reality and representation, knowledge and belief, the opposition between

\footnotetext{
${ }^{8}$ Most clearly after the Milesian cosmologists, who might for that reason be better considered proto-scientists.
} 
materialists who 'define reality as the same thing as body' and idealists who hold that 'true reality consists in certain intelligible and bodiless forms' (Sophist 246a-b; ibid: 990), the question of 'why the creator made this world of generation' (Timaeus 29d-e; ibid.: 1162), and so on. It is just as easy to see how such reflections might result in ethical conclusions, whether on the basis that there is a meaning of life, as in Plato's case, or that there is not one, as with the French Existentialists. And it is not much harder to see how other paradigmatically philosophical concerns might then have been brought in, such as aesthetics, which some philosophers saw as a clue to life's meaning (Kant) or a respite from its lack of one (Schopenhauer); or logic and linguistic analysis, which some philosophers (Russell) saw as the key to addressing philosophy’s traditional epistemological and metaphysical problems. $^{9}$

Of course, you might think that Plato and perhaps some other ancient philosophers are isolated cases, and that philosophy has typically not shown much interest in the meaning of life. But that only looks plausible if you restrict your attention to analytic philosophy. Outside of that tradition, it has been more or less explicitly pivotal to the thought of many of the bestknown Western philosophers; Julian Young (2014) brings this out well. But even when it is not so explicit - as it generally was before philosophy began to part company from theology in the seventeenth century - a concern with the meaning of life is not hard to discern in all those great philosophers who sought to interweave metaphysical, epistemological and moral doctrines into a unified system, especially when God - or the non-existence of God - is central. Spinoza, for instance, tells us that his philosophical quest began when he realised

\footnotetext{
${ }^{9}$ I can only hint at how the meaning of life can form the basis of a fully inclusive conception of philosophy here, but I go into considerably more detail in [deleted], where I argue that philosophy is best construed as a prototype concept (Laurence and Margolis 1999: 27 ff.)
} 
'that all the usual surroundings of social life are vain and futile' (Spinoza 1662 / 1887: 3); it was a worry about the meaning of life that drove him to philosophy, and the certitudes of his system address that worry exactly.

Analytic philosophy has typically, though not always (Ayer op. cit.; Smart 1963), taken a more piecemeal approach to this cluster of topics. But the fact that this obscures any unifying factor does not mean it has not remained simmering beneath the surface. The main problem with the recent renaissance of interest in the meaning of life among analytic philosophers is that it has taken a direction which further covers this over. This new paradigm becomes explicit in Susan Wolf (Wolf 1997 / 2008), and has found its most prolific and enthusiastic advocate in Thaddeus Metz. It proceeds by stating paradigm-cases of meaningful lives (e.g. Mandela, Picasso, Einstein) and then working through an apparently endless stream of intuitions in an attempt to isolate the factors which make such lives meaningful. By this means, some activities are found to add meaning to life (producing great art), some are found to detract from it (prostitution), and some are found to be neutral (eating chocolate). Metz even thinks that a meaningfulness calculus can be produced in this way, with scores for anything we might do (Metz 2013: 234).

The main problem with this new paradigm is not that it seeks the meaning of life within human society rather outside of it; this follows a venerable tradition stemming from Nietzsche, albeit one which those in the new paradigm studiously ignore, rather as they ignore the well-established area of empirical psychology that investigates attributions of meaningfulness in a manner which takes into account cultural variation (e.g. Steger et al. 2008; Mason 2013). The main problem is that it typically proceeds by dismissing or ignoring the traditional question, or worse, by encouraging its conflation with the new paradigm's 
distinct question. That the questions are distinct is clear enough, because if life can be placed in a wider meaningful context, it might turn out that Mandela did not have a meaningful life; perhaps he had a socially meaningful life, but achieving social meaningfulness is not the meaning of life. And if there is no such context, then his life was as meaningless as everyone else's. Tolstoy's famous reflections on the meaning of life take as their starting point the fact that his life had accrued exceptional levels of social meaningfulness (Tolstoy 1882 / 1987). Yet despite his prodigious achievements, Tolstoy still wonders if his life has any meaning.

New Paradigmers push this question to one side, saying for instance that 'this metaphysical or cosmological question of meaning need not deter us here’ (Kaupinnen 2012: 352), or that their interest is only in 'what ordinary folk actually mean by the expression in question' (Brogaard and Smith 2005: 444). This is not so bad on the dubious premise that there is a distinctive concept of social meaningfulness that merits specifically philosophical investigation; but the culminative effect of the literature is to suggest that this is the only interesting question in the area, or that it is what the traditional question amounts to. Metz is the main culprit. Thus he justifies his neglect of " "holist" or "cosmic" questions' on the grounds that he is discussing what '[m]ost people, or at least philosophers, interested in topics readily placed under the rubric ‘the meaning of life' ultimately want to know' (Metz op. cit.: 3); the history of philosophy (and literature), however, stands squarely opposed to this assertion. ${ }^{10}$ And he encourages conflation when at the end of his book, he asks whether his theory of social meaningfulness is 'the holy grail of Western normative philosophy' (ibid.: 249). But of course, anything which might justifiably go under this title would be an answer

\footnotetext{
${ }^{10}$ Metz does not even stick to his guns; see ibid.: chapter 13, which is all about the traditional question, despite his promise at the start of the book that he was not going to discuss it.
} 
to the traditional question; if it had normative consequences, they would flow from its metaphysical characterisation of reality.

Still, perhaps something good will come of the new paradigm, since it may inadvertently renew interest in the traditional question. Not that I expect 'the holy grail' to be discovered, because I do not think there is one; though I do think there are plenty of fruitful philosophical implications to explore from life's lack of meaning. ${ }^{11}$ However when it comes to the metaphilosophical question of philosophy's subject-matter, the meaning of life cannot be ignored, since it is the only issue that provides everything we need. It unites the traditional problems of philosophy within a field of interest which explains why philosophers have wanted a maximally general description of reality. It brings together theoretical and practical concerns. It predominates at the start of all the great philosophical traditions, and opened up concerns which all subsequent movements can be related to. It is an issue in the public domain, as would be expected of the subject-matter of an ancient discipline. And since it is not obsolete, we cannot be accused of simply offering an account of the origins of philosophy, as you might provide an account of the origins of chemistry in alchemy. Philosophy has moved on, but the issue that unites its concerns remains live.

\section{Let's Embrace the Popular Image}

If this is right, you might well wonder why it is not more widely known within the philosophical profession. There is something to be said for a one-word answer to this:

embarrassment. But there was of course no deliberate cover-up. Rather I think embarrassment played its part along the following lines.

${ }^{11}$ See [deleted] 
Philosophers, like any group of professionals, want to be taken seriously, and for this you need an area of expertise. Philosophers have felt this need particularly acutely because they cannot rely on experimental methodology as scientists do, and yet their subject-matter encourages them to proclaim on matters such as the nature of knowledge, morality, or reality itself. The latter prevents them from appealing to literary, artistic or historical expertise, and naturally aligns them with science rather than the humanities, which also seeks to accurately describe reality, rather than simply interpret it. But lacking experimental methodology, philosophy began to look like a pale shadow of science once the latter began to dominate culture; a superseded attempt to do the same kind of thing, as Comte saw it. This led philosophers to devise technical methods and identify with them, as per methodological accounts of philosophy. And to peacefully co-exist with science, they also had to distance their discipline from religion, with which science was increasingly at odds.

Thus philosophers continued to discuss whether God exists, but came to think of philosophy of religion as simply another 'philosophy of x', where x can be any topic you like. And the combination of this distancing from religion, with philosophy's need for an exclusive area of expertise, is what relegated the meaning of life to the side-lines. For not only is it ineluctably associated with religion, it is also the kind of popular topic which practically everyone feels qualified to take a stance on: priests, spiritualists, scientists, artists, the proverbial man-downthe-pub ... it is an embarrassingly amateurish topic. That continental philosophy has not shown similar reticence is a product of the dogged antipathy to science it has typically maintained, and the fact that it has developed its own means for excluding non-professionals; namely through exceptionally obscure prose styles, rather than the technical methods of the 
analytic philosophers. Discussion of the meaning of life could thereby be more easily disguised as inquiries into being, nothingness, and the like.

Moreover concern with the meaning of life is peculiarly badly suited to a professional selfimage because it is has pathological connotations. According to clinical psychologist Raymond Bergner, worrying about the meaning of life is a 'relatively common' problem for people, which arises as 'part of a broader clinical syndrome, such as depression, alcoholism, posttraumatic stress disorder, or obsessive-compulsive personality disorder' (Bergner 1998: 73). To treat it, he recommends promoting new patterns of behaviour, while discouraging clients from seeking an intellectual solution (ibid.: 79-80). Against this backdrop, then, which colours the public perception of the issue and partly explains why the meaning of life (and by extension philosophy) has been the butt of popular jokes from Monty Python to Douglas Adams, it is hardly surprising that philosophers would not be keen to emphasise it.

I think these are the main factors which have led to the meaning of life being excluded from the self-image of professional philosophy. But held up to the light of day, there is no good reason for this. Concern with the meaning of life need not be pathological; it is a legitimate intellectual issue of widespread and potentially universal interest, and without philosophy there would be no academic specialism to service it. ${ }^{12}$ Philosophical treatments of this issue need not be connected to religion, as most from the last hundred years have not been, and through knowledge of the history of philosophy and its methodologies, philosophers have the expertise to say considerably more interesting and valuable things about it than anyone else.

\footnotetext{
${ }^{12}$ I am here discounting the idea raised earlier that biologists, for instance, might be able to address it. It seems clear to me that they cannot, because the question makes essential reference to the possibility of transcendence; see [deleted].
} 
But in any case, accepting that this is the issue that unifies the discipline does not require philosophers to pay any attention to it; most can safely ignore it and focus their attention on the various other issues it has opened up over philosophy's long history.

Embracing the meaning of life might actually work wonders for philosophy's public profile. The preconception is there in any case, and confounding it with exceptionalist theses leaves philosophy looking both nebulous and aloof. Moreover, it might discourage philosophyscepticism among other academics, especially scientists, and consequently their regular, amateurish infringements into philosophical territory. With a basic grasp of what philosophy is about, perhaps Stephen Hawking might discern a specifically philosophical interpretation of our 'yearn[ing] to know why we are here and where we came from’ (Hawking 1988: 14), and thereby not be so inclined to denigrate philosophy for dereliction of its traditional duty to answer such questions by failing to keep up with developments in physics. And with a more sophisticated grasp of philosophy's subject-matter - for which a basic one is a good start philosophers might attain better understanding of the progress their discipline has achieved. But whatever other benefits this might bring, it does at least answer a crashingly obvious question about philosophy which, through a combination of circumstances, the profession has become embarrassingly evasive about: namely 'what's it all about?'

There is something exceptional about philosophy: the etymology of its name provides no clue to its subject-matter. This is because it was once used much more widely, and was only relatively recently co-opted to distinguish philosophy as we know it from other fields of learning. This, no doubt, has been a major source of the obfuscation we have seen. But the name was appropriate, if uninformative, because it refers us to the cluster of topics which were central preoccupations of the Greek philosophers, with whom 'philosophy' will always 
be indelibly linked. That the naming came late provides no reason to think a unified subjectmatter was not being named. And once named, thinkers who discuss only isolated aspects of it are easily identified as philosophers. In a pedantic sense - which would not ordinarily be intended by such a phrase - philosophy is obviously not all about the meaning of life; it is about lots of different things. Saying what any discipline is all about in that sense will prove an uphill struggle which is unlikely to get you anywhere interesting. But in the sense that would be ordinarily intended, I think philosophy is all about the meaning of life. If you wanted to move beyond that to a working definition, then perhaps: 'philosophy is the study of a range of related issues concerning knowledge, reality and moral conduct, which traditionally centre on the question of life's meaning'. 


\section{Bibliography}

Ayer, A.J. (2002) Language, Truth and Logic, New York: Dover Publications.

Bergner, R. (1998) 'Therapeutic Approaches to Problems of Meaninglessness’, American Journal of Psychotherapy, 52: 72-87.

Brandom, R. (2001) 'Reason, Expression, and the Philosophic Enterprise’, in C. Ragland and S. Heidt (eds.) What is Philosophy? New Haven and London: Yale University Press.

Brogaard, B. and Smith, B. (2005) 'On Luck, Responsibility and the Meaning of Life’, Philosophical Papers, 34: 443-58.

Clarke, J. J. (1997) Oriental Enlightenment: The Encounter between Asian and Western Thought, London: Routledge.

Comte, A. (1974) The Essential Comte, ed. S. Andreski, trans. M. Clarke, London: Croom Helm.

Cooper, D. (2003) Meaning, Chesham: Acumen.

Derrida, J. (1978) Writing and Difference, trans. A. Bass, Chicago: University of Chicago Press.

Derrida, J. (1987) The Postcard: From Socrates to Freud and Beyond, trans. A. Bass, Chicago: University of Chicago Press.

Flew, A. (1979) A Dictionary of Philosophy, London: Macmillan.

George, A. (trans.) (1999) The Epic of Gilgamesh, London: Penguin Books.

Hawking, S. (1988) A Brief History of Time, New York: Bantom.

Kauppinen, A. (2012) ‘Meaningfulness and Time’, Philosophy and Phenomenological Research, 84: 345-77.

Klemke, E.D. (2008) ‘Living Without Appeal: An Affirmative Philosophy of Life’, in E. Klemke and S.Cahn (eds.) The Meaning of Life: A Reader, $3^{\text {rd }}$ edn, Oxford: Oxford University Press. 
Knobe, J. and Nichols, S. (eds.) (2008) Experimental Philosophy, Oxford: Oxford University Press.

Knobe, J. and Nichols, S. (2008) ‘An Experimental Philosophy Manifesto’, in their Experimental Philosophy, Oxford: Oxford University Press.

Laurence, S. and Margolis, E. (1999) 'Concepts and Cognitive Science’, in S. Laurence and E. Margolis (eds.) Concepts: Core Readings, Cambridge, MA: MIT Press.

Mason, H. (2013) 'Meaning in Life Within an African Context: A Mixed Method Study’, Journal of Psychology in Africa, 23: 635-8.

May, R. (1996) Heidegger's Hidden Sources: East-Asian Influences on his Work, London: Routledge.

McGinn, C. (1993) Problems in Philosophy, Oxford: Blackwell.

McGinn, C. (2008) Sport, Durham, UK: Acumen Press.

Metz, T. (2013) Meaning in Life, Oxford: Oxford University Press.

Plato (1961) The Collected Dialogues of Plato, eds. E. Hamilton and H. Cairns, Princeton: Princeton University Press.

Quine, W.V.O. (1975) ‘A Letter to Mr. Ostermann’, in C. Bontempo and S. Jack Odell (eds.) The Owl of Minerva: Philosophers on Philosophy, New York: McGraw-Hill.

Rorty, R. (1982) 'Philosophy as a Kind of Writing: An Essay on Derrida', in his Consequences of Pragmatism, Minneapolis: University of Minnesota Press.

Rorty, R. (1991) 'Letter 4’ in A. Balslev, Cultural Otherness: Correspondence with Richard Rorty, Atlanta: Scholars Press.

Russell, B. (1959) Wisdom of the West: A historical survey of Western philosophy in its social and political setting, Garden City, NY: Doubleday.

Smart, J.J.C. (1963) Philosophy and Scientific Realism, London: Routledge. 
Smith, B. (ed.) (2007) Questions of Taste: The Philosophy of Wine, Oxford: Oxford University Press.

Spinoza, B. (1887) Tractatus de Intellectus Emendatione, in The Chief Works, trans. R.H.M. Elwes, London: George Bell and Sons.

Steger, M., Kawabata, Y., Shimai, S. and Otake, K. (2008) 'The meaningful life in Japan and the United States: Levels and correlates of meaning in life', Journal of Research in Personality, 42: 660-78.

Stoljar, D. (2010) Physicalism, London: Routledge.

Tolstoy, L. (1882 / 1987) ‘My Confession’, in O. Hanfling (ed.) Life and Meaning, Oxford: Basil Blackwell.

Turner, D. (2011) Paleontology: A Philosophical Introduction, Cambridge: Cambridge University Press.

Urmson, J. (1960) 'Editor’s Introduction', in The Concise Encyclopaedia of Western Philosophy and Philosophers, London: Hutchinson.

Williamson, T. (2007) The Philosophy of Philosophy, Oxford: Blackwell.

Wolf, S. (2008) 'Meaning in Life', in E. Klemke and S. Cahn (eds.) The Meaning of Life: A Reader, $3^{\text {rd }}$ edn, Oxford: Oxford University Press.

Wood, A. (2001) ‘Philosophy: Enlightenment Apology, Enlightenment Critique’, in C. Ragland and S. Heidt (eds.) What is Philosophy? New Haven and London: Yale University Press.

Young, J. (2014) The Death of God and The Meaning of Life, $2^{\text {nd }}$ edn, London: Routledge. 